\title{
Impacts of more frequent droughts on a relict low-altitude Pinus uncinata stand in the French Alps
}

\section{Christophe Corona ${ }^{1,2}$, Jérôme Lopez-Saez ${ }^{3}$, Markus Stoffel ${ }^{2,4}{ }^{*}$, Georges Rovéra ${ }^{5}$, Jean-Louis Edouard ${ }^{6}$ and Frédéric Guibal ${ }^{7}$}

${ }^{1}$ Centre National de Recherche Scientifique UMR6042 GEOLAB, Clermont-Ferrand, France

${ }^{2}$ Laboratory of Dendrogeomorphology, Department of Exogene Geology, Institute of Geological Sciences, University of Bern, Bern, Switzerland

${ }^{3}$ IRSTEA, UR EMGR, Saint Martin d'Hères, France

${ }^{4}$ Climatic Change and Climate Impacts, Institute for Environmental Sciences, University of Geneva, Geneva, Switzerland

${ }^{5}$ Centre National de Recherche Scientifique, Université Joseph Fourier UMR 5194 PACTE, Grenoble, France

${ }^{6}$ Aix Marseille Université, CNRS, Ministère de la Culture et de la Communication, CCJ UMR 7299, 13094, Aix en Provence, France

7 Centre National de Recherche Scientifique UMR 7263 IMBE, Aix-en-Provence, France

\section{Edited by:}

Franco Biondi, University of Nevada,

Reno, USA

\section{Reviewed by:}

Eryuan Liang, Chinese Academy of Sciences, China

Marc Macias-Fauria, University of

Oxford, UK

\section{*Correspondence:}

Markus Stoffel, Climate Change and

Climate Impacts, University of

Geneva, Route de Drize 7, $\mathrm{CH}-1227$

Carouge, Geneva, Switzerland

e-mail: markus.stoffel@dendrolab.ch
Cold microclimatic conditions provide exceptional microhabitats to Pinus uncinata stands occurring at abnormally low altitudes in seven relict stands of the northern French Alps. Here, P. uncinata is located at the lower bounds of its ecological limits and therefore expected to provide a sensitive indicator of climate change processes. We used dendrochronological analysis to study the growth patterns of closely spaced chronologies across an elevational transect and compare a relict low-altitude to a $P$. uncinata stand located at the alpine treeline. Two detrending procedures are used to reveal high- and low-frequencies embedded in annually resolved ring-width series. Growth response of $P$. uncinata to instrumental temperature and precipitation data is investigated by means of moving response function analyses. Results show an increase in the sensitivity of tree-ring widths to drought during previous summer in both stands. At the treeline stand, an increasing response to fall temperature is observed whereby fall temperature and radial tree growth increased in two synchronous steps around $\sim 1930$ and from $\sim 1980$-present. At the low-altitude stand, $P$. uncinata appears more drought sensitive and exhibits a sharp growth decline since the mid-1980s, coinciding with increasing summer temperatures. Growth divergence between the two stands can be observed since the mid-1980s. We argue that the positive growth trend at the high-altitude stand is due to increasing fall temperatures which would favor the formation of metabolic reserves in conjunction with atmospheric $\mathrm{CO}_{2}$ enrichment that in turn would facilitate improved water use efficiency. At the relict low-altitude stand, in contrast, it seems that improved water use efficiency cannot compensate for the increase in summer temperatures.

Keywords: relict pine stand, tree-growth decline, climate change, dendroclimatology, response functions, French Alps

\section{INTRODUCTION}

In the Northern French Alps, Mountain pines (Pinus uncinata Mill. ex Mirb.) are usually at their optimum in the subalpine belt between 1600 and $2300 \mathrm{~m}$ a.s.l. (Rolland and Schueller, 1995), but seven stands have been reported to grow at abnormally low elevations within a mountain belt of the Rhone Alpes and at altitudes comprised between 1100 and $1500 \mathrm{~m}$ a.s.l. The existence of these exceptional stands in the Devoluy (Combe Obscure; Bertinelli et al., 1993; Bois du Sappey; Cécillon et al., 2010) and Grande Chartreuse (La Plagne cirque; Cassagne et al., 2008) massifs was associated with the circulation of cold air in scree slopes, which may locally create periglacial pedoclimatic conditions (Cécillon et al., 2010). The microclimate of cold scree slopes allows for exceptional microhabitats to develop with very thick and raw humus (Cassagne et al., 2008), forming ideal niches for various cold living plants (Bertinelli et al., 1993) and periglacial relict species of non-vascular plants (Asta et al., 2001), beetles (Molenda, 1996), spiders and mites (Zacharda et al., 2005). These microhabitats, which are older than the surrounding biological matrix, act as refugia by supporting relict communities unable to survive elsewhere in the landscape. In these refugia, $P$. uncinata is located at the lower elevation bounds of its ecological limits and can therefore be expected to be a sensitive indicator of climate change processes (e.g., Oberhuber et al., 2008). Furthermore, in these open, low-production forests both competition between species and forestry operations are very limited. As a consequence, we though hypothesized that these low-altitude P. uncinata stands may bear an important and "pure" imprint of accelerated warming observed in the Alpine region in the last three decades (Böhm et al., 2010; Corona et al., 2010a,b).

This study presents results from a relict low-altitude $P$. uncinata stand situated on a north-facing slope void of periglacial 
edaphic conditions, and where growth dynamics are expected to be reflective of changes in climatic conditions. Based on extensive dendrochronological analyses, we compare growth patterns of closely spaced $P$. uncinata chronologies across an elevational transect from a low-altitude (LAS, $1150 \mathrm{~m}$ asl) to a high altitude stand (HAS, $1900 \mathrm{~m}$ asl) located at treeline. In particular, we (i) identify high- to low-frequencies embedded in annually resolved ring-width series; (ii) use response function analyses to investigate growth responses in $P$. uncinata to instrumental temperature and precipitation records; (iii) compare ring-width chronologies from LAS and HAS with monthly mean temperature and precipitation data; and (iv) discuss growth-climate responses as well as climate related growth shifts.

\section{STUDY SITES}

The two sites investigated are located within the Parc National des Ecrins $\left(45^{\circ} 02^{\prime} \mathrm{N}, 6^{\circ} 8^{\prime} \mathrm{E}\right)$ where the most easterly of the lowaltitude $P$. uncinata stands of the northern French Alps have been identified (Figures 1A,B). The stands are located on the northfacing Liassic limestone-schist slopes of the Grande Aiguille and the Petite Aiguille (Oisans massif, Isère). The stands, formed almost exclusively of $P$. uncinata, occupy an area of $\sim 130$ ha located between 1150 and $1900 \mathrm{~m}$ a.s.l., with roughly one hundred individuals located at abnormally low altitudes. The low-altitude stand has been described in the literature as a cold subalpine enclave in a montane ecosystem dominated by beech-fir (FagusAbies) and Norway spruce (Picea abies (L.) Karst.) forests (Godron and Salomez, 1995). The cold climatic conditions associated with these north-facing, steep slopes are conducive to low-altitude colonization by mesocryophilic P. uncinata (Rameau et al., 1993; Petitcolas, 1998). Ground flora is characterized by an important moss cover, species typical for raw humus soils (Rhododendron ferrugineum L., Vaccinium vitis-idaea L., V. myrtillus L.) and accompanied by subalpine calciphilic species (Dryas octopetala L., Saxifraga oppositifolia L. or Arctostaphylos uva-ursi (L.) Spreng.). The stands grow on relatively shallow soils, predominantly protorendzina, i.e., rendzic and lithic leptosols with moder humus according to the FAO classification system (IUSS Working Group WRB, 2006). They consist of unconsolidated, coarse-textured materials with low water holding capacity. Distinct soil horizons are hardly ever developed.

Climate at the study site is reflective of continental conditions observed in the intra-alpine zone of the French Alps. Mean annual precipitation (1951-2007) at the Saint-Christophe-enOisans $\left(44^{\circ} 56^{\prime} \mathrm{N}, 6^{\circ} 11^{\prime}, 1570 \mathrm{~m}\right)$ weather station located $3 \mathrm{~km}$ east of the study site is $974 \pm 186 \mathrm{~mm}_{\text {year }}^{-1}$ with a rainfall minimum in summer (mainly July and August) and a rainfall maximum in autumn. Mean annual temperature is $5.9^{\circ} \mathrm{C}$ with 148 days year $^{-1}$ of freezing.

\section{MATERIALS AND METHODS FIELD COLLECTION AND SAMPLE PREPARATION}

P. uncinata trees were sampled at LAS (1150 $\mathrm{m}$ asl) and HAS (i.e., treeline, $1900 \mathrm{~m}$ asl) where slope steepness ranges between $15^{\circ}$ and $25^{\circ}$. A total of 72 trees (36 at LAS and 36 at HAS, Figure 2A) with absence of major stem or crown anomalies (due to lightning, wind or snow breakage) was sampled and two increment cores extracted per tree from opposing radii (144 increment cores). Ring widths were measured to the nearest $0.01 \mathrm{~mm}$ using a digital LINTAB positioning table connected to a Leica stereomicroscope and TSAPWin Scientific software (Rinntech, 2009).

\section{CHRONOLOGY DEVELOPMENT AND STATISTICS}

Prior to detrending, all ring-width series were screened for missing rings and dating errors using COFECHA (Cook and Holmes, 1984). Comparison of the LAS and HAS chronologies was performed using a recent version of ARSTAN (Cook, 1985) and included Mean Sensitivity (MS) to represent the mean of the relative deviations between consecutive rings for a given tree (Fritts, 1976) and to assess high-frequency variations in the chronologies. In addition, first-order serial autocorrelation (AC) was used to detect the persistence retained in the chronologies.

Expressed Population Signal (EPS) quantifies the degree to which the constructed chronology portrays hypothetically perfect conditions (Wigley et al., 1984). We used an EPS threshold of 0.85 to determine the reliability of our chronologies. Two conceptually different standardization methods were used for this study, namely (i) a hybrid "double-detrending" which is more accurate as far as high-frequency variations concerned (Cook and Peters, 1981), as well as (ii) an Adaptative Regional Growth Curve standardization (ARGC, Nicault et al., 2010) where long-term trends in chronologies are preserved. Indices from the first detrending were used for the response function analyses and relate to the high-frequency growth variations. After smoothing both the tree-ring and meteorological series with 10- and 20-year low pass filters, the indices from the second detrending were visually compared with (multi-) decadal climate variations.

For the "double-detrending," an initial negative exponential or linear regression was applied for each raw measurement series, followed by a fitting of a 30-year cubic smoothing spline with $50 \%$ frequency response cut-off (Cook and Peters, 1981). Then, for each stand, the growth indexes were averaged by year using a bi-weighted robust mean to develop a stand chronology which represented the common high frequency variation of the individual series (Cook, 1987).

The ARGC standardization (Nicault et al., 2010) was employed to preserve potential low-frequency climate variability. The ARGC approach is in fact a refinement of the Regional Curve Standardization (RCS; Briffa et al., 1992) and based on the adaptation of the RCS to each tree by taking into account the differences in cambial age and mean productivity which are functions of competition and soil (Rathgeber et al., 2000). Practically, tree-ring series are standardized into relative tree-ring indices by dividing each measured ring by its expected value estimated from a growth trend (Equation 1). An Artificial Neural Network (ANN; Nicault et al., 2010) was then used to estimate the ARGC for each tree from its cambial age, as well as initial and maximum productivity (Equation 2). In the present case we used a feed-forward network trained with an error back-propagation learning algorithm (Rumelhart et al., 1986) and took account of productivity (i.e., indexed series) on the basis of juvenile growth characteristics as follows:

$$
\mathrm{It}=\mathrm{Ct} / \mathrm{Yt}
$$



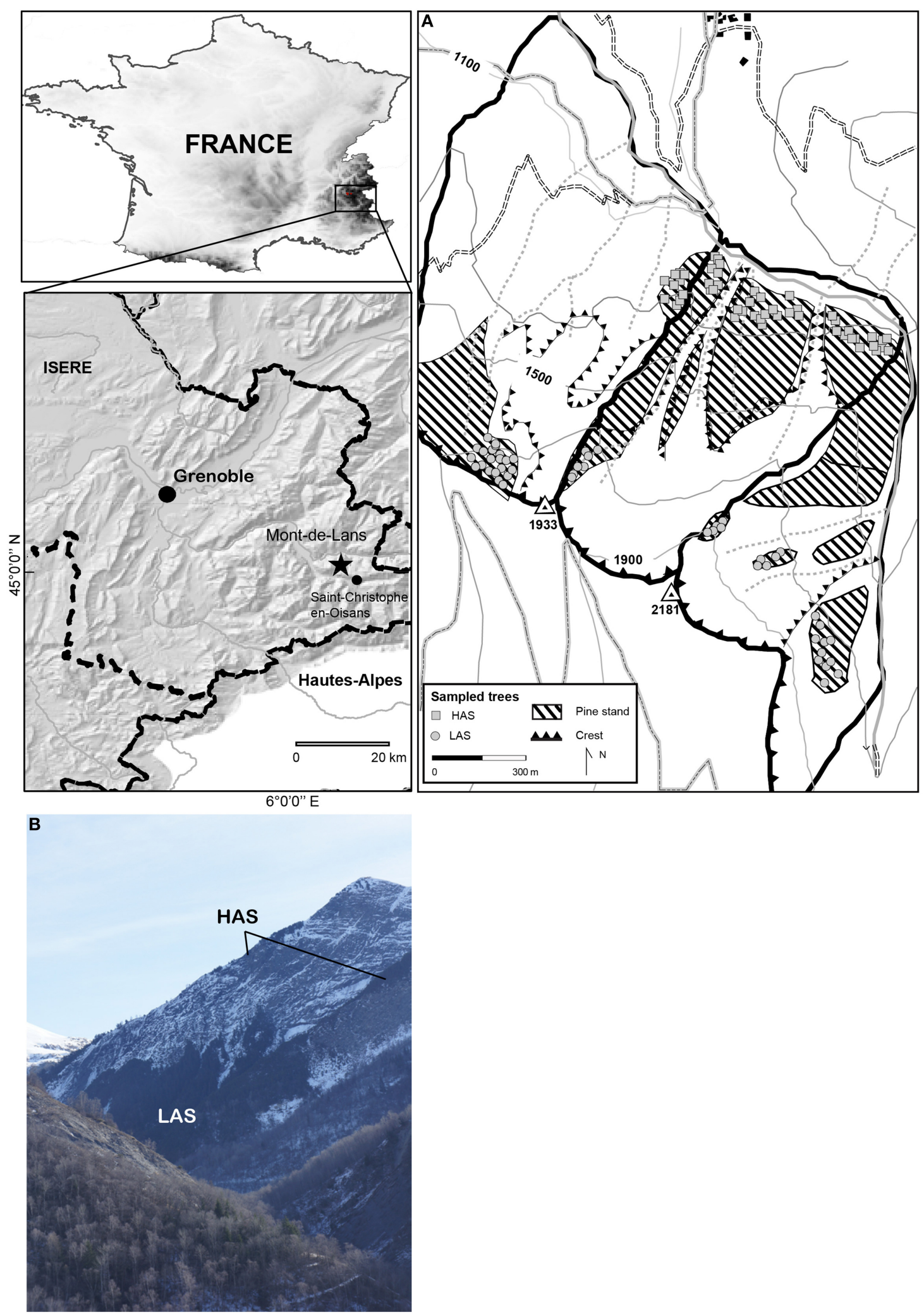

FIGURE 1 | (A) Location of the Grande Aiguille study site in the Northern French Alps; (B) Impressions of low (LAS) and high (HAS) altitude P. uncinata stands. 


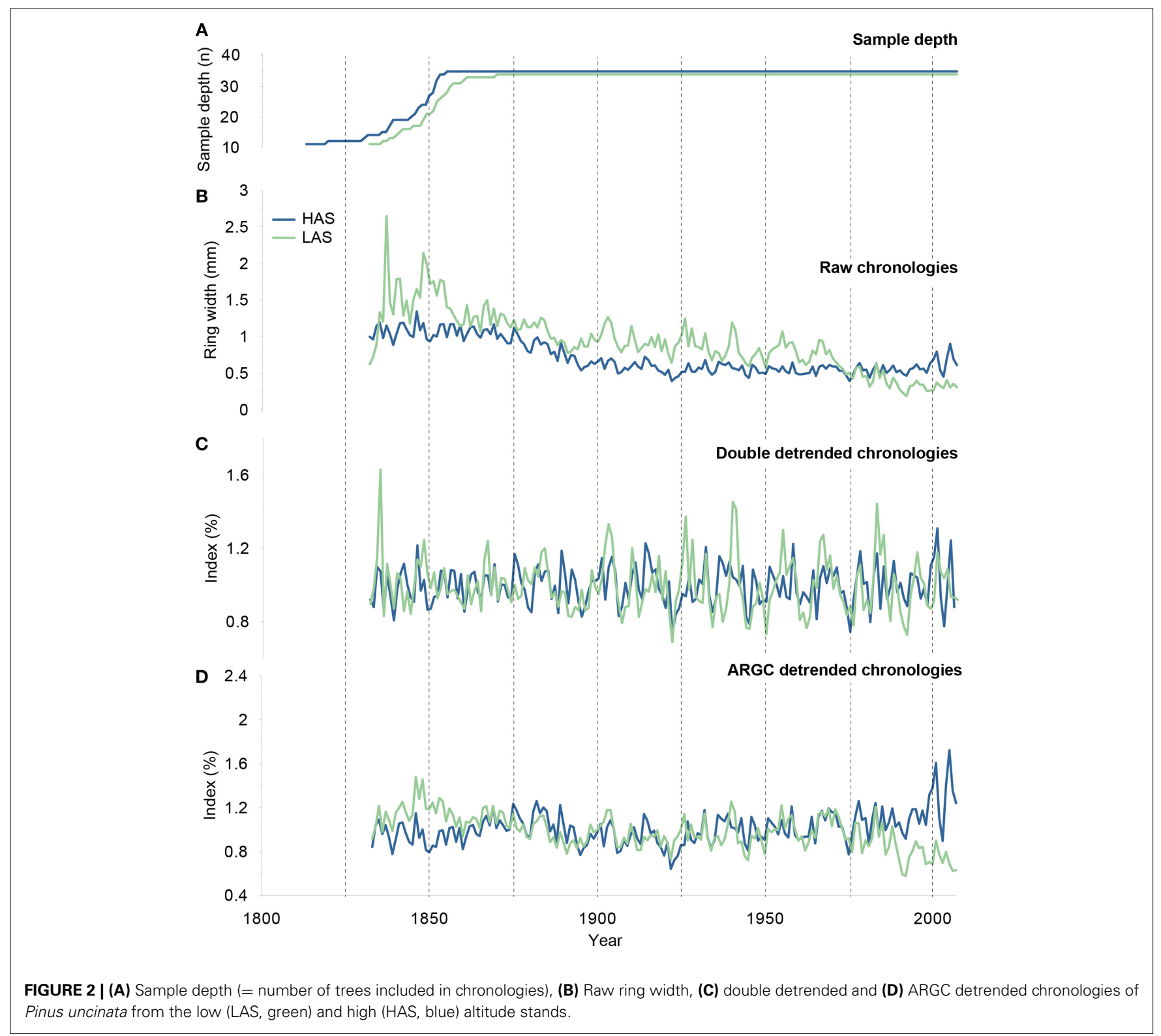

$$
\mathrm{Yt}=\mathrm{F}(\alpha(\mathrm{Ct}), \mathrm{g}(\mathrm{C}), \mathrm{G}(\mathrm{C}))
$$

where It is the tree-ring index, $\mathrm{Ct}$ the measured tree-ring width, Yt the theoretical value of tree ring $\mathrm{Ct}, \alpha(\mathrm{Ct})$ the age of tree ring $\mathrm{Ct}, \mathrm{g}(\mathrm{C})$ the initial growth of tree $\mathrm{C}$, i.e., the average of the first 10 rings, $G(C)$ is the maximum juvenile growth of tree $\mathrm{C}$, i.e., the maximum value reached during its juvenile stage (first 50 year) after smoothing with a 10 year window. As ANN fits each tree, detrending is not sensitive to the occurrence of missing rings at the tree's pith (Nicault et al., 2010). The approach has been demonstrated to be particularly well-suited to heterogeneous Alpine environments (Corona et al., 2010a,b) where rapid variations in soils, microclimate, competition and other factors governing site productivity may induce major divergence in tree-growth rates.

\section{CLIMATE DATA SETS}

Long instrumental series of meteorological parameters are largely lacking in the French Alps (Corona et al., 2010b). For the purpose of response function calibration, we therefore used homogenized temperature and precipitation records from the HISTALP dataset (Efthymiadis et al., 2006; Böhm et al., 2010). This database extends back to $\mathrm{AD} 1760$ and covers the Greater Alpine Region (GAR, $4-19^{\circ} \mathrm{E}, 43-49^{\circ} \mathrm{N}, 0-3500 \mathrm{~m}$ asl). Data is represented as deviations from the 1961-1990 mean with a latitude-longitude resolution of $0.1^{\circ} \times 0.1^{\circ}$ for precipitation and $1^{\circ} \times 1^{\circ}$ for temperature. Given the large variability of climate in the Alps, especially for precipitation, we used mean monthly series of temperature and precipitation from the four HISTALP grid points located nearest to the $P$. uncinata stands $\left(6-7^{\circ} \mathrm{E}, 44-45^{\circ} \mathrm{N}\right.$ for temperature; $6^{\circ} 05^{\prime}-6^{\circ} 15^{\prime} \mathrm{E} ; 44^{\circ} 55^{\prime}-45^{\circ} 05^{\prime} \mathrm{N}$ for precipitation). Pearson's correlation analysis with the meteorological series of 
Saint-Christophe-en-Oisans (located near the stands) revealed highly significant coefficients for the time interval covered by both series (1951-2007).

\section{CLIMATE GROWTH RELATIONSHIPS}

In order to test for the sensitivity of the relict $P$. uncinata stand to climate change, climate-growth relationships have been tested with response function analyses, a form of principal component regression designed to account for collinearity of monthly climate predictors (Fritts, 1976). Bootstrapped climategrowth Response Functions (RF) were computed between double detrended chronologies and monthly climate predictors using the Dendroclim 2002 software (Biondi and Waikul, 2004).

The climatic dataset from the HISTALP database included mean monthly air temperature $\left({ }^{\circ} \mathrm{C}\right)$ and total monthly precipitation $(\mathrm{mm})$ sequenced from May of the year preceding the formation of the tree ring $(t-1)$ to September of the year of actual tree-ring formation $(t)$, yielding a set of 34 predictors. To evaluate the stationarity and consistency of responses over time, we computed Moving Response Functions (MRF) by progressively shifting the period of a fixed number of years across time to compute response function coefficients (Biondi and Waikul, 2004). To provide a sufficiently large number of degrees of freedom, the length of the calibration period was double than the number of predictors ( 34 in this study), so that only periods $>68$ years were considered. RF and MRF produce a temporal set of coefficients for each monthly predictor, whereby statistical significance at $p<0.05$ was tested using a bootstrap procedure (Biondi and Waikul, 2004).

\section{RESULTS}

\section{CHRONOLOGY DESCRIPTIVE STATISTICS}

Two ring-width chronologies were developed for each stand (LAS and HAS, Figure 2B), whereby most tree-ring series show the typical age-related exponential decrease in ring width, also known as age trend. EPS values meet the signal strength acceptance in both chronologies $(>0.85,0.88$ in HAS, 0.89 in LAS) from 1837 to 2007. High first-order autocorrelation (0.83 in HAS and 0.79 in LAS) indicates that radial growth throughout the slope was strongly influenced by conditions in the preceding year. Differences of mean sensitivities are rather small between both stands (0.19 in HAS, 0.18 in LAS).

\section{RESPONSE FUNCTION ANALYSIS}

Double detrended ring-width chronologies used for the calculation of RF and MRF are depicted in Figure 2C. RF coefficients were computed for the common period 1837-2007. They differ slightly between HAS and LAS (Figure 3A) with RF profiles showing that the dominant factors controlling tree-ring widths at HAS and LAS are summer (mainly July and August) temperatures and precipitations in the year preceding tree-ring formation. This influence is particularly acute at LAS. In contrast, below-average May to June temperatures combined with above-average precipitation totals between April and June of the year of growth-ring formation favored radial growth at LAS.

\section{STATIONARITY OF THE MONTHLY CLIMATE RESPONSES OVER TIME}

At LAS, MRF analysis revealed that the negative response of tree growth to summer temperatures (JAS) in the year preceding tree-ring formation $(t-1)$ as well as positive influence of summer precipitation totals in July and August have been stable since 1837 (Figures 3B,C). At HAS, a significant response is observed for $t-1$ July temperature and radial growth, provided that the calibration interval ends before 1980. In addition, positive response is also fairly obvious between $t$-1 August temperatures and radial growth and sharply increased around 1930 (Figure 3B).

At LAS, temporally stable key climate variables are represented by $t$ June temperature and April precipitation (Figures 3B,C). The strength of the negative response between $t$ May temperature and ring width increased in recent decades and becomes significant provided that the calibration interval ends after the 1940s. Current ( $t$ ) May, June and July precipitation were the most significant predictors of radial growth at HAS.

Several factors have been identified by the RFs as not being significant over the entire period but still having a periodic influence on tree growth. Among these, $t-1$ November temperature was a significant predictor of radial growth of LAS trees in case that the calibration interval ends after 1980, whereas the regression estimates increased as soon as the calibration period ends after the mid-1930s at HAS. At LAS, the negative relation of radial growth with $t$ August temperatures was even reversed in the last decade.

\section{ANALYSIS OF GROWTH TRENDS}

ARGC detrended ring-width chronologies are depicted in Figure 2D and are designed to maximize low-frequency information. In Figure 4A, ARGC chronologies from HAS are plotted with mean fall (October-November) temperature after a z-transformation and smoothing by a 20 -year low-pass filter. We observe that low-frequency variability of temperature and radial tree growth increased in two synchronous steps at ca. 1930 and ca. 1980. Using a 10-year smoothing, HAS chronologies (Figure 4B) show a decadal variability in radial tree growth with depressions in $1860,1895,1920,1945,1975$, and 1990 and a clear positive trend since the early 1990s. Decadal ring-width fluctuations properly coincide with rainfall totals during the vegetation period (which locally lasts from May to September, Figure 4B).

At LAS, depressions in radial growth are observed in 1895, $1935,1945,1960$, and 1990. A negative trend is clearly visible since the 1960 (Figure 4C) and low ring-width values concur with below-average July to September precipitation in 1945, 1975, and 1990. In addition, negative coincidence is observed between July to September (JAS) temperature and the LAS ring-width oscillations since the 1940s (Figure 4D). Particularly, the growth decline observed in LAS smoothed tree-ring chronology since the 1980s coincides with positive JAS temperature anomalies.

\section{DISCUSSION}

\section{RELATIONSHIP BETWEEN CLIMATE AND RADIAL GROWTH}

In our study, growth of $P$. uncinata was above all limited by drought in the summer preceding tree-ring formation $(t-1)$ and by precipitation in May and June of the year of radial growth $(t)$ at both the low- and high-elevation stands (Figure 3A). The predominance of meteorological conditions of the previous growing 


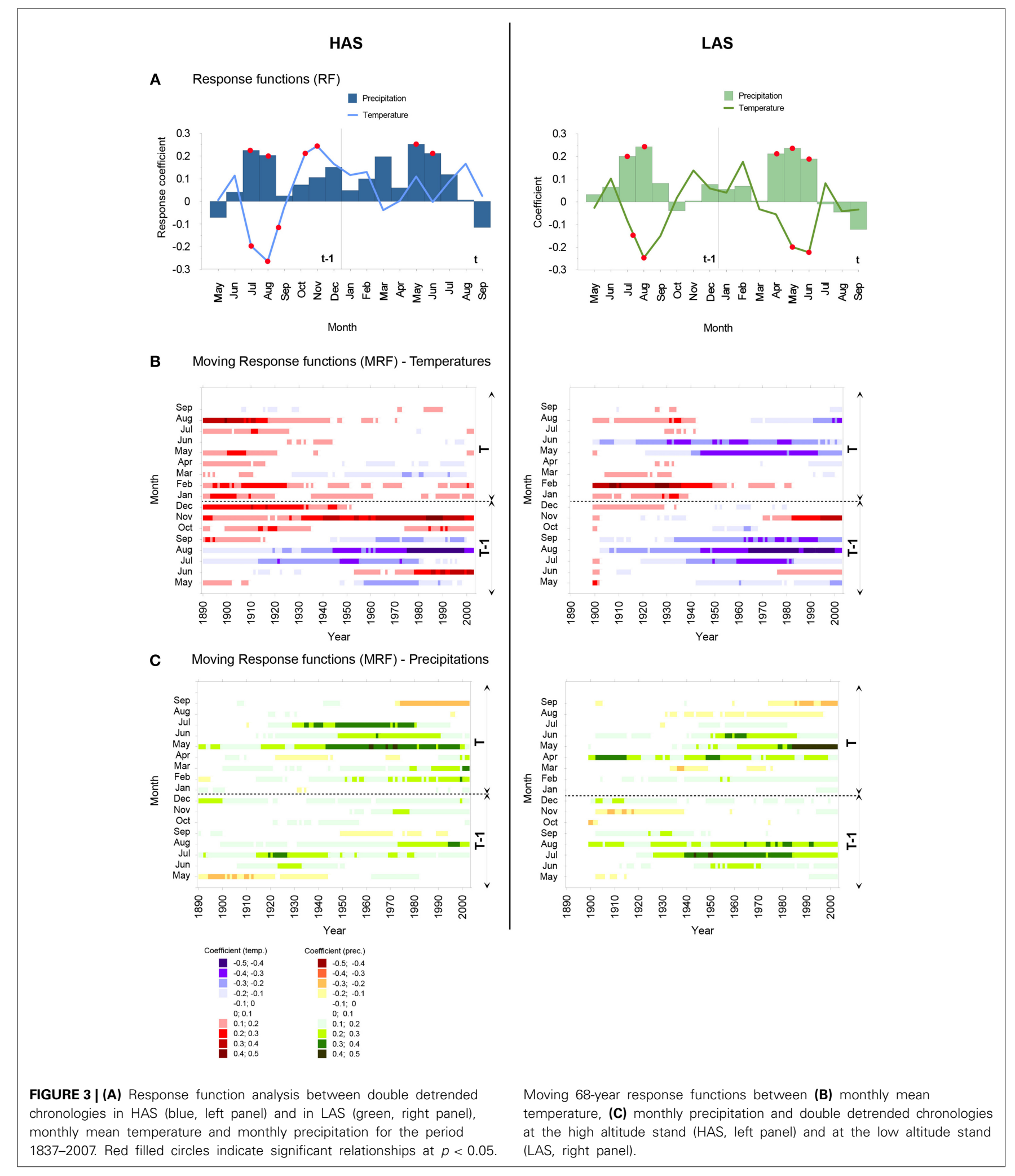

season on current radial growth has been reported for other P. uncinata stands in the French Alps (Rolland and FlorenceSchueller, 1998) and the Spanish Pyrenees (Gutiérrez, 1991; Tardif et al., 2003). Limited radial growth occurring after dry $t$ - 1

summers likely reflects restricted root growth and/or the depletion of stored reserves (Petitcolas, 1998). Similarly, the positive response of radial growth of $P$. uncinata to spring precipitation has been reported in other subalpine belts of the French 
A

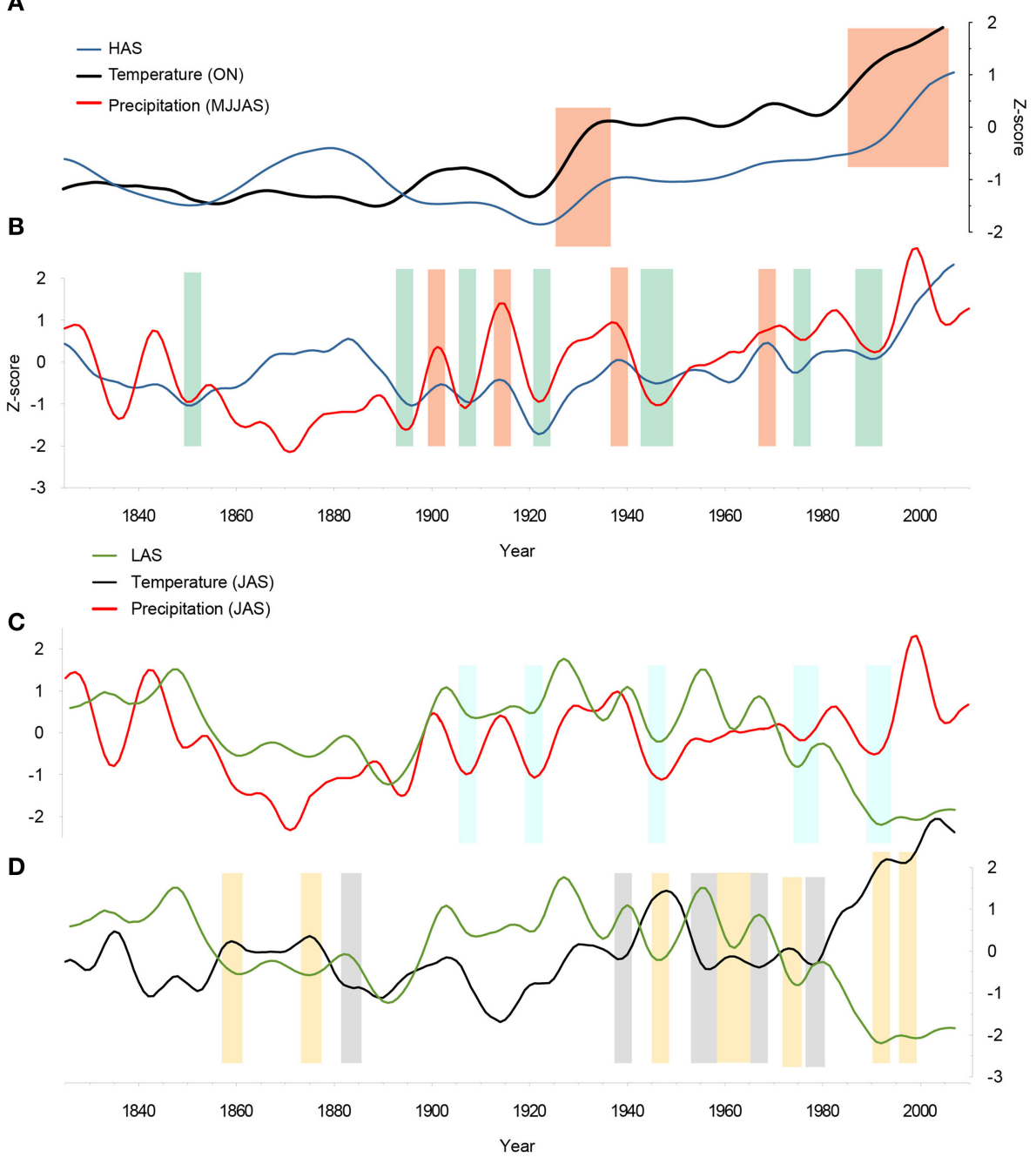

FIGURE 4 | Comparison of low-pass filtered ARGC detrended chronologies and key climate variables for the period 1837-2007: (A) 20-year low-pass filtered HAS chronology and Fall (ON) temperature; (B) 10-year low-pass filtered HAS chronology and May to September precipitations; (C) 10-year low-pass filter LAS chronology, summer (JJA) temperatures and (D) precipitations. Both the climate series and the tree-ring chronologies were transformed to z scores over the 1837-2007 common period. Orange (green) bars emphasize synchronous periods of growth increase (decrease) in tree rings. Based on visual comparison, blue bars emphasize periods of growth decrease coinciding with negative JAS precipitation anomalies. Yellow bars indicate periods of growth decline coinciding with positive JAS temperature anomalies. Gray bars indicate periods of tree-growth increase synchronous with negative JAS temperature anomalies.
Alps, (Rolland and Schueller, 1996; Petitcolas, 1998) and for $P$. sylvestris and $P$. cembra stands growing in dry inner alpine valleys (Oberhuber et al., 1998, 2008; Rigling et al., 2002; Pfeifer et al., 2005). At our sites, growth limitations are probably favored by the presence of shallow and poorly developed soils on schists with low water-holding capacity.

The growth of individuals at HAS is positively correlated with temperatures in $t-1$ autumns. These findings are in agreement with results of Rolland and Schueller (1996) and Petitcolas (1998) for north-facing $P$. uncinata stands of the Briançon area where low temperatures in $t-1$ autumn are likely to limit the formation of metabolic reserves and to consequently affect radial growth in year $t$ (Rolland and Schueller, 1995). Similar observations have been reported for P. cembra by Pfeifer et al. (2005) and Gruber et al. (2010). As photosynthesis can occur until late October (i.e., after the termination of growth processes) under favorable conditions (Tranquillini, 1959), sugar can be stored and will be available at the beginning of the next growing season (Wardle, 1971). As a consequence, warm October and November temperatures will facilitate carbon storage, promote mycorrhizal root growth by maintaining soils above freezing and favor maturation of needles, shoots and buds against detrimental effects of winter stress (Oberhuber et al., 2008).

At LAS, $P$. uncinata trees appear to be drought sensitive with high temperature at the beginning of the growing period also being a limiting factor for cambial activity. This specific relationship was not previously observed at alpine treeline sites (Rolland and Schueller, 1996) and contradicts results of previous 
studies realized in the French Alps and the Pyrenees (Rolland and Schueller, 1995; Tardif et al., 2003) for which May temperature was positively correlated with tree-ring width.

\section{TEMPORAL EVOLUTION OF MONTHLY CLIMATE RESPONSES}

A temporal change of months significantly correlated with radial growth was found for the LAS and HAS stands since AD 1837. We observe that negative (positive) relationship with $t$-1 August ( $t$-1 November) temperature has increased since 1837, therefore suggesting that carry-over effects (such as photosynthetic gain, or the storage of assimilates and water from the $t-1$ growing season) would have impacted increasingly current-year $(t)$ radial growth over the course of the 20th century (Kozlowski and Pallardy, 1997). In a similar way, increasingly positive relationships between growth and precipitation at the beginning of the growing period (May) seem to be closely affected by increasing spring-summer temperatures controlling soil moisture balance (Martínez-Vilalta et al., 2008).

At LAS, the increasing negative relationship with mean temperature in May indicates exacerbated moisture stress at the onset of the growing period (Figures 3B,C). In that sense, results are in agreement with studies from drought-stressed populations of other coniferous species in the Mediterranean (Martin-Benito et al., 2010) and North America (Biondi, 2000).

\section{RISING TEMPERATURES AS A DRIVER OF DIVERGENT GROWTH}

At HAS, radial growth of $P$. uncinata exhibits successive stages of increase starting around 1920 and 1980 synchronous with increases in October and November temperature (Figure 4A). Comparable results were reported for $P$. uncinata in the French Alps (Rolland et al., 1998) and for P. cembra in the central Swiss Alps (Vittoz et al., 2008), where increased radial growth could be successfully correlated with mild autumn temperatures since the 1980s.

Conversely, the $P$. uncinata trees sampled at LAS exhibit a strong negative growth trend since the mid-1980s. The sharp decline observed in radial growth since the mid-1980s is likely reflective of increasing summer temperatures. Results from LAS are thus in line with other studies reporting growth decline in other Pinus sp. for various sites in the Mediterranean (see MartinBenito et al., 2010 for a review), more xeric treeline locations in boreal forests (Lloyd and Fastie, 2002) or within dry inneralpine valleys where altered temperatures have been held responsible for increased mortality of susceptible or less competitive species (Bigler et al., 2006).

\section{POSSIBLE EFFECTS OF OTHER ENVIRONMENTAL FACTORS ON TREE GROWTH DIVERGENCES BETWEEN SITES}

Given the poor productivity of stands growing close to or at the treeline, difficult access to the study sites as well as the sylvopastoral activity practiced in the region since the Middle Ages (Allix, 1929), forestry operations such as selective harvesting (Rolland et al., 1998) can be excluded as a driver of changes in growth in our 19th century relict $P$. uncinata stand. As a consequence, two drivers may be involved in explaining divergent tree growth between HAS and LAS from 1980 onwards, namely enrichment of atmospheric $\mathrm{CO}_{2}$ and/or a deposition of $\mathrm{N}$ from air pollution by $\mathrm{NO}_{2}$.

Increased atmospheric $\mathrm{CO}_{2}$ concentrations have been suggested as a possible driver of changes. The $\mathrm{CO}_{2}$ fertilization effect would result in increased water-use efficiency (WUE) mainly due to partial closure of stomata and to a rise of the temperature optimum of photosynthesis (Broadmeadow and Randle, 2002; Keenan et al., 2013). Such a $\mathrm{CO}_{2}$-induced increase of WUE is associated with greater net primary productivity and positive growth trends and at high elevation sites (e.g., LaMarche et al., 1984; Keenan et al., 2013), It is more evident at sites with greater stress and more severely limited resources (Martínez-Vilalta et al., 2008), as is the case at HAS and other Pinus stands in the Alps and the Mediterranean (Leal et al., 2008; Martínez-Vilalta et al., 2008). However, recent studies also point to the fact that temperatureinduced drought may limit C uptake (Barber et al., 2000). Lower C uptake during dry summers may cancel out increased uptake in spring (Angert et al., 2005). At LAS, we can thus hypothesize that an improvement of WUE (if any) cannot compensate for the increase in summer temperatures as shown for other species such as P. sylvestris (Martínez-Vilalta et al., 2008) and F. sylvatica (Jump et al., 2006) at their southern distribution ranges.

As a result of the proximity of our study sites to a major city and a main highway, possible effects of $\mathrm{N}$ deposition and its interactions with increased $\mathrm{CO}_{2}$ concentrations should be considered as well when addressing drivers of growth in $P$. uncinata, as increased $\mathrm{N}$ uptake from soil could allow $\mathrm{N}$-deficient forests to respond to elevated $\mathrm{CO}_{2}$. Tree growth might be particularly sensitive to such ecological effects because (i) alpine habitats are known to be strongly N-limited (Bowman, 1992) and as (ii) the benefit from $\mathrm{N}$ fertilization has been shown to be higher in nutrient-limited soils (Hattenschwiler et al., 1996; Huang et al., 2007). Both sites used in this study have mainly poor, shallow soils and $\mathrm{N}$ deposition has possibly contributed, along with the $\mathrm{CO}_{2}$ increase, to boost tree growth at HAS, but fails to explain the divergence observed between the stands since the 1980s.

\section{CONCLUSION}

This study is among the first to detail the dendroclimatic response of a low altitude $P$. uncinata relict forest stand located at the lower bounds of its altitudinal limits (Pawlowsky, 1970). Our results demonstrate that tree growth has been driven increasingly by summer droughts, in particular and much more severely during the last $\sim 30$ year. Our findings provide evidence of divergence in growth between relict low (LAS) and the high-altitude (HAS) $P$. uncinata stands since the 1980s. At HAS, response function suggest that increasing autumn temperatures have favored radial growth presumably as a result of longer growing season (Penuelas et al., 2009). Response functions also suggest that the pronounced and continuous growth decline at LAS seems to be driven by higher summer temperatures and increased soil water stress in summer. The relict stand at LAS can be seen as a model case for the evolution of forests in the subalpine belt as well as for dynamics of trees located at the lower bounds of their ecological range. 


\section{REFERENCES}

Allix, A. (1929). Un Pays de Haute Montagne: lóisans, Étude Géographique Réédition de 1929, Laffitte, Marseille, 1975. Thèse lettres, Université de Grenoble, Grenoble.

Angert, A., Biraud, S., Bonfils, C., Henning, C. C., Buermann, W., Pinzon, J., et al. (2005). Drier summers cancel out the $\mathrm{CO}_{2}$ uptake enhancement induced by warmer springs. Proc. Natl. Acad. Sci. U.S.A. 102, 10823-10827. doi: 10.1073/pnas.0501647102

Asta, J., Orry, F., Toutain, F., Souchier, B., and Villemin, G. (2001). Micromorphological and ultrastructural investigations of the lichen-soil interface. Soil Biol. Biochem. 33, 323-337. doi: 10.1016/S0038-0717(00)00143-7

Barber, V. A., Juday, G. P., and Finney, B. P. (2000). Reduced growth of Alaskan white spruce in the twentieth century from temperature induced drought stress. Nature 405, 668-673. doi: 10.1038/35015049

Bertinelli, F., Petitcolas, V., Asta, J., Richard, L., and Souchier, B. (1993). Dynamic relations between vegetation and soil on cold scree in Southern French Alps (relations dynamiques entre la végétation et le sol sur éboulis froid dans les Alpes françaises méridionales). Rev. Ecol. Alp. 2, 93-104.

Bigler, C., Bräker, O. U., Bugmann, H., Dobbertin, M., and Rigling, A. (2006). Drought as an inciting mortality factor in Scots pine stands of the Valais, Switzerland. Ecosystems 9, 330-343. doi: 10.1007/s10021-005-0126-2

Biondi, F. (2000). Are climate-tree growth relationships changing in north-central Idaho? Arctic Antarct. Alp. Res. 32, 111-116. doi: 10.2307/1552442

Biondi, F., and Waikul, K. (2004). DENDROCLIM2002: a C++ program for statistical calibration of climate signals in tree-ring chronologies. Comput. Geosci. 30 303-311. doi: 10.1016/j.cageo.2003.11.004

Böhm, R., Jones, P. D., Hiebl, J., Frank, D., Brunetti, M., and Maugeri, M. (2010). The early instrumental warm-bias: a solution for long central European temperature series 1760-2007. Clim. Change 101, 41-67. doi: 10.1007/s10584009-9649-4

Bowman, W. D. (1992). Inputs and storage of nitrogen in winter snowpack in an alpine ecosystem. Arctic Alp. Res. 24, 211-215. doi: 10.2307/1551659

Briffa, K. R., Jones, P. D., Bartholin, T. S., Eckstein, D., Schweingruber, H. F., Karlen, W., et al. (1992). Fennoscandian summers from AD 500: temperature changes on short and long timescales. Clim. Dyn. 7, 111-119. doi: 10.1007/BF002 11153

Broadmeadow, M., and Randle, T. (2002). "The impacts of increased $\mathrm{CO}_{2}$ concentrations on tree growth and function," in Climate Change: Impacts on UK Forest, Chapter 9, ed M. Broadmeadow (Edinburgh: Forestry Comission Bulletin 125), 119-140.

Cassagne, N., Spiegelberger, T., Cécillon, L., Juvy, B., and Brun, J. J. (2008). The impact of soil temperature increase on organic matter and faunal properties in a frozen calcareous scree in the French Alps. Geoderma. 146, 239-247. doi: 10.1016/j.geoderma.2008.05.028

Cécillon, L., De Mello, N. A., De Danieli, S., and Brun, J. J. (2010). Soil macroaggregate dynamics in a moutain spatial gradient. Biogeochemistry 97, 31-43. doi: 10.1007/s10533-009-9341-9

Cook, E. R. (1985). A Time Series Analysis Approach to Tree-Ring Standardization. $\mathrm{Ph} . \mathrm{D}$. thesis, University of Arizona.

Cook, E. R. (1987). The decomposition of tree-ring series for environmental studies. Tree-Ring Bull. 47, 37-59.

Cook, E. R., and Holmes, R. L. (1984). Program ARSTAN User Manual: Laboratory of Tree Ring Research. Tucson, AZ: University of Arizona.

Cook, E. R., and Peters, K. (1981). The smoothing spline: a new approach to standardizing forest interior tree-ring width series for dendroclimatic studies. Tree-Ring Bull. 41, 45-53.

Corona, C., Edouard, J. L., Guibal, F., Guiot, J., Bernard, S., Thomas, A., et al. (2010b). Long-term summer (AD751-2008) temperature fluctuation in the French Alps based on tree-ring data. Boreas. 40, 351-366. doi: 10.1111/j.15023885.2010.00185.x

Corona, C., Guiot, J., Edouard, J. L., Chalié F., Büntgen, U., Nola, P., et al. (2010a), Millennium-long summer temperature variations in the European Alps as reconstructed from tree-rings. Clim. Past 6, 379-400. doi: 10.5194/cp-6-3792010

Efthymiadis, D., Jones, P. D., Briffa, K. R., Auer, I., Böhm, R., Schöner, W., et al. (2006). Construction of a 10-min-gridded precipitation data set for the greater alpine region for 1800-2003. J. Geophys. Res. 111:D01105. doi: 10.1029/2005JD006120

Fritts, H. C. (1976). Tree Rings and Climate. New York, NY: Academic Press.
Godron, M., and Salomez, P. (1995). Delphine, Inventaire et Cartographie des Milieux. Gap: Atelier Technique des Espaces Naturels, Parc National des Ecrins.

Gruber, A., Pirkebner, D., Oberhuber, W., and Wieser, G. (2010). Spatial and seasonal variations in mobile carbohydrates in Pinus cembra in the timberline ecotone of the Central Austrian Alps. Eur. J. For. Res. 130, 173-179. doi: 10.1007/s10342-010-0419-7

Gutiérrez, E. (1991). Climate tree-growth relationships for Pinus uncinata Ram. in the Spanish pre-Pyrenees. Acta Oecol. 12, 213-225.

Hattenschwiler, S., Schweingruber, F. H., and Körner, C. (1996). Tree ring responses to elevated $\mathrm{CO}_{2}$ and increased $\mathrm{N}$ deposition in Picea abies. Plant Cell Environ. 19, 1369-1376. doi: 10.1111/j.1365-3040.1996.tb00015.x

Huang, J. G., Bergeron, Y., Denneler, B., Berninger, F., and Tardif, J. (2007). Response of forest trees to increased atmospheric $\mathrm{CO}_{2}$. Crit. Rev. Plant Sci. 26, 265-283. doi: 10.1080/07352680701626978

IUSS Working Group WRB. (2006). World Reference Base for Soil Resources 2006 World Soil Resources Reports No. 103, FAO, Rome.

Jump, A. S., Hunt, J. M., and Peñuelas, J. (2006). Rapid climate change related growth decline at the southern range edge of Fagus sylvatica. Glob. Change Biol. 12, 2163-2174. doi: 10.1111/j.1365-2486.2006.01250.x

Keenan, T. F., Hollinger, D. Y., Bohrer, G., Dragoni, D., Munger, J. W., Schmid, H. P., et al. (2013). Increase in forest water-use efficiency as atmospheric carbon dioxide concentrations rise. Nature 499, 324-327. doi: 10.1038/nature12291

Kozlowski, T. T., and Pallardy, S. G. (1997). Physiology of Woody Plants. San Diego, CA: Academic Press.

LaMarche, V. C., Graybill, D. A., Fritts, H. C., and Rose, M. R. (1984). Increasing atmospheric carbon dioxide: tree ring evidence for growth enhancement in natural vegetation. Science 225, 1019-1021. doi: 10.1126/science.225.4666.1019

Leal, S., Derek, E., Grabner, M., Wimmer, R., and Cherubini, P. (2008). Tree rings of Pinus nigra from the Vienna basin region (Austria) show evidence of change in climatic sensitivity in the late 20th century. Can. J. For. Res. 38, 744-759. doi: 10.1139/X07-189

Lloyd, A. H., and Fastie, C. L. (2002). Spatial and temporal variability in the growth and climate response of treeline trees in Alaska. Clim. Change 52, 481-509. doi: 10.1023/A:1014278819094

Martin-Benito, D., Rio, M., and Canellas, I. (2010). Black pine (Pinus nigra Arn.) growth divergence along a latitudinal gradient in Western Mediterranean mountains. Ann. For. Sci. 67, doi: 10.1051/forest/2009121

Martínez-Vilalta, J., López, B. C., Adell, N., Badiella, L., and Ninyerola, M. (2008). Twentieth century increase of Scots pine radial growth in NE Spain shows strong shows strong climate interactions. Glob. Change Biol. 14, 1868-2881. doi: 10.1111/j.1365-2486.2008.01685.x

Molenda, R. (1996). Zoogeographische Bedeutung Kaltluft erzeugender Blockhalden im auberalpinen Mitteleuropa: Untersuchungen an Arthropoda, insbesondere Coleoptera. Verh. naturwiss. Ver. Hamburg 35, 5-93.

Nicault, A., Guiot, J., Brewer, S., and Edouard, J. L. (2010). Preserving long-term climatic changes in standardisation of tree-ring series by the Adaptative Regional Growth Curve (ARGC). Dendrochronologia 28, 1-12. doi: 10.1016/j.dendro.2008.02.003

Oberhuber, W., Kofler, W., Pfeifer, K., Seeber, A., Gruber, A., and Wieser, G. (2008). Long-term changes in tree-ring-climate relationships at Mt. Patscherkofel (Tyrol, Austria) since the mid-1980s. Trees 22, 31-40. doi: 10.1007/s00468-0070166-7

Oberhuber, W., Stumböck, M., and Kofler, W. (1998). Climate-tree-growth relationships of Scots pine stands (Pinus sylvestris L.) exposed to soil dryness. Trees 13, 19-27.

Pawlowsky, B. (1970). Remarques sur l'endémisme dans la flore des Alpes et des Carpates. Vegetatio 21, 181-243. doi: 10.1007/BF02269663

Penuelas, J., Rutishauser, T., and Filella, I. (2009). Ecology. Phenol. Feedbacks Clim. Change Sci. 324, 887-888. doi: 10.1126/science.1173004

Petitcolas, V. (1998). Dendroécologie Comparée de L'épicéa, du Mélèze, du Pin Cembro et du Pin à Crochets en Limite Supérieure de la Forêt Dans les Alpes Françaises: Influence de la Variabilité Macro-Écologique. Ph.D. thesis, University of Grenoble.

Pfeifer, K., Kofler, W., and Oberhuber, W. (2005). Climate related causes of distinct radial growth reductions in Pinus cembra during the last 200 years. Vegetation Hist. Archaeobot. 14, 211-220. doi: 10.1007/s00334-005-0001-2

Rameau, J. C., Mansion, D., Dumé, G., Lecointe, A., Timbal, J., Dupont, P., et al. (1993). Flore forestiére française. Guide Écologique Illustré, Tome 2, Montagnes. 
Dijon-Quetigny: Institut pour le Développement forestier, Ministére de l'Agriculture et de la Pêche, Direction de l'Espace rural et de la Forêt, École nationale du Génie rural, des Eaux et des Forêts.

Rathgeber, C., Nicault, A., Guiot, J., Keller, T., Guibal, F., and Roche, P. (2000). Simulated responses of Pinus halepensis forest productivity to climatic change and CO increase using a statistical model. Glob. Planet. Change, 26, 405-421. doi: 10.1016/S0921-8181(00)00053-9

Rigling, A., Bräker, O. U., Schneiter, G., and Schweingruber, F. H. (2002). Intraannual tree-ring parameters indicating differences in drought stress of Pinus sylvestris forests within the Erico-Pinion in the Valais (Switzerland). Plant Ecol. 163, 105-121. doi: 10.1023/A:1020355407821

Rinntech. (2009). LINTAB_-Precision Ring by Ring. Available online at: http:// www.rinntech.com/Products/LINTAB.htm

Rolland, C., and Florence-Schueller, J. (1998). Dendroclimatological synthesis on mountain pine (Pinus uncinata Mill. ex Mirb.) in the Pyrenees and the Alps. Ecologie 29, 417-421.

Rolland, C., Petitcolas, V., and Michalet, R. (1998). Changes in radial tree growth for Picea abies, Larix decidua, Pinus cembra and Pinus uncinata near the alpine timberline since 1750. Trees Struct. Funct. 13, 40-53.

Rolland, C., and Schueller, J. (1995). Comparaison dendroécologique de trois pinèdes de Pin à crochets (Pinus uncinata Mill. ex Mirb.) dans les Alpes occidentales externes, intermédiaires et internes. Dendrochronologia 13, 85-95.

Rolland, C., and Schueller, J. (1996). Dendroclimatologie du Pin à crochets (Pinus uncinata Mill. ex Mirb.) dans le Briançonnais et le Queyras en fonction des conditions stationnelles. Schweiz. Z. Forstwesen 147, 351-363.

Rumelhart, D. E., Hinton, G. E., and Williams, R. J. (1986). Learning representations by back-propagating errors. Nature 323, 533-536. doi: 10.1038/323533a0

Tardif, J., Camarero, J. J., Ribas, M., and Gutiérrez, E. (2003). Spatiotemporal variability in tree growth in the central Pyrenees climatic and site influences. Ecol. Monogr. 73, 241-257. doi: 10.1890/0012-9615(2003)073[0241:SVITGI]2.0.CO;2

Tranquillini, W. (1959). Die Stoffproduktion der Zirbe (Pinus cembra L.) an derWaldgrenze während eines Jahres. Planta 54, 107-151. doi: 10.1007/BF01901679

Vittoz, P., Rulence, B., Largey, T., and Freléchoux, F. (2008). Effects of climate and land-use change on the establishment and growth of Cembran pine (Pinus cembra L.) over the altitudinal treeline ecotone in the central Swiss Alps. Arctic Antarct. Alp. Res. 40, 225-232. doi: 10.1657/1523-0430(06010)[VITTOZ]2.0.CO;2

Wardle, P. (1971). An explanation for alpine timberline. N. Z. J. Bot. 9, 371-402. doi: 10.1080/0028825X.1971.10430192

Wigley, T. M., Briffa, K. R., and Jones, P. D. (1984). On the average value of correlated time series, with applications in dendroclimatology and hydrometeorology. J. Clim. Appl. Meteorol. 23, 201-213.

Zacharda, M., Gude, M., Kraus, S., Molenda, R., and Ruzicka, V. (2005). The relict mite Rhagidia gelida (Acari, Rhagidiidae) as a biological cryoindicator of periglacial microclimate in European highland screes. Arctic Antarct. Alp. Res. 37, 402-408. doi: 10.1657/1523-0430(2005)037[0402:TRMRGA] 2.0.CO;2

Conflict of Interest Statement: The authors declare that the research was conducted in the absence of any commercial or financial relationships that could be construed as a potential conflict of interest.

Received: 16 May 2014; accepted: 28 November 2014; published online: 20 January 2015.

Citation: Corona C, Lopez-Saez J, Stoffel M, Rovéra G, Edouard J-L and Guibal F (2015) Impacts of more frequent droughts on a relict low-altitude Pinus uncinata stand in the French Alps. Front. Ecol. Evol. 2:82. doi: 10.3389/fevo.2014.00082

This article was submitted to Paleoecology, a section of the journal Frontiers in Ecology and Evolution.

Copyright (C) 2015 Corona, Lopez-Saez, Stoffel, Rovéra, Edouard and Guibal. This is an open-access article distributed under the terms of the Creative Commons Attribution License (CC BY). The use, distribution or reproduction in other forums is permitted, provided the original author(s) or licensor are credited and that the original publication in this journal is cited, in accordance with accepted academic practice. No use, distribution or reproduction is permitted which does not comply with these terms. 